\title{
Architektura informacji w piśmiennictwie zagranicznym 1982-2018. Analiza ilościowa
}

\author{
Anna Matysek \\ Wydziat Filologiczny, Instytut Bibliotekoznawstwa i Informacji Naukowej \\ Uniwersytet Ślaski w Katowicach
}

\begin{abstract}
Abstrakt
Cel/Teza: Celem artykułu jest przedstawienie procesu kształtowania się zainteresowania problematyką architektury informacji w światowym piśmiennictwie.

Koncepcja/Metody badań: Rozwój literatury dotyczącej architektury informacji przebadano na podstawie analizy bibliometrycznej piśmiennictwa zagranicznego na ten temat, opublikowanego do końca 2018 r. Piśmiennictwo to zostało zidentyfikowane na podstawie baz Scopus, Web of Science i Library and Information Science Abstract oraz serwisów Google Scholar, Google Books i księgarni Amazon. Analizę ilościową rozkładu chronologicznego i tematycznego piśmiennictwa uzupełnia wskazanie najważniejszych autorów, książek i czasopism, a także najczęściej cytowanych publikacji. Wyniki i wnioski: Zidentyfikowano 2269 publikacji dotyczących problematyki architektury informacji o bardzo zróżnicowanej tematyce, przede wszystkim z zakresu systemów informacyjnych i nauki o informacji. Wyniki analizy wskazują, że zainteresowanie różnymi aspektami architektury informacji zwiększa się nieprzerwanie od 2000 r., co zostało potwierdzone rosnącą liczbą publikacji i ich cytowań. Oryginalność/Wartość poznawcza: $\mathrm{W}$ polskim piśmiennictwie nie podejmowano dotychczas próby analizy literatury z zakresu architektury informacji. Artykuł może być punktem wyjścia do pogłębionej analizy tematycznej oraz stanowić materiał porównawczy dla podobnych badań.
\end{abstract}

\section{Słowa kluczowe}

Analiza bibliometryczna. Analiza ilościowa piśmiennictwa. Architektura informacji. Architektura systemów informacyjnych. Nauka o informacji.

Otrzymany: 1 lutego 2019. Zrecenzowany: 26 lutego 2019. Poprawiony: 9 marca 2019. Zaakceptowany: 13 marca 2019.

\section{Wprowadzenie}

Architektura informacji (AI), rozumiana jako działalność praktyczna związana z porządkowaniem informacji i nadawaniem im logicznych struktur, funkcjonuje odkąd ludzie nauczyli się komunikować (Skórka, 2016, 557). Sam termin jest stosunkowo młody, początkowo w latach 70. XX w. funkcjonował jako „the architecture of information” (León, 2014) w jednym z projektów realizowanych w firmie Xerox. Za ojca terminu „information architecture” i pioniera tej dyscypliny uważa się Richarda Saula Wurmana (Cooper, 2009). Ważną rolę w przybliżeniu omawianego zagadnienia odegrała książka Information architecture for the World Wide Web, której pierwsze wydanie ukazało się w 1998 r. (Morville \& Rosenfeld, 1998) i w której autorzy w przystępny sposób omówili komponenty AI oraz 
proces i metodologię jej projektowania. Rodrigo Ronda León przeanalizował najważniejszą literaturę z zakresu architektury informacji z lat 80. i 90. XX wieku, wskazując, że jest to nowa i praktyczna dyscyplina, w związku z czym niewiele jest tekstów poświęconych tematom historycznym i teoretycznym (León, 2014). W kolejnej analizie literatury z omawianego zakresu wyszczególniono sześć kluczowych aspektów AI (jakość informacji, metadane, informacja i proces, metodologia, kwestie organizacyjne oraz wyzwania i udane praktyki) oraz wykazano, że wciąż odgrywa ona ważną rolę w zapewnianiu efektywnego dostępu do informacji (Martin et al., 2010).

Wraz z rozwojem technologii informacyjno-komunikacyjnych wzrastało znaczenie architektury informacji jako dyscypliny kształtującej cyfrowe przestrzenie informacyjne zgodnie z potrzebami użytkowników. Rozwój Internetu i różnorodność jego usług spowodowały nie tylko zwiększenie ilości informacji, ale nastąpiły także rewolucyjne zmiany w dostępie do niej, w sposobach gromadzenia, organizowania i prezentowania zasobów informacyjnych, informacja stała się wszechobecna, stawiając nowe wyzwania przed omawianą dyscypliną (Resmini \& Rosati, 2011).

W Polsce koncepcję architektury informacji jako pierwszy przedstawił Stanisław Skórka (Skórka, 2002), a Barbara Sosińska-Kalata wykazała, że temat ten stanowi ważny obszar badawczy w nauce o informacji (Sosińska-Kalata, 2007). W ostatnich latach wzrasta zainteresowanie tą dyscypliną w aspekcie kształcenia akademickiego (Tafiłowski, 2016). Jednakże krajowa literatura w tym zakresie nie jest zbyt obszerna. Dominują teksty S. Skórki, jest także kilka artykułów innych autorów. Ponadto na język polski przetłumaczono kilka książek: Architektura informacji w serwisach internetowych drugie (Rosenfeld \& Morville, 2003) i czwarte wydanie (Rosenfeld, Morville, \& Arango, 2017), Wzorce wyszukiwania (Morville \& Callender, 2011) oraz Projektowanie nawigacji stron WWW (Kalbach, 2012).

Ze względu na skromny zasób polskojęzycznych publikacji podejmujących problematykę AI, na co wskazywał też Piotr Tafiłowski (Tafiłowski, 2016), oraz rosnącą popularność kształcenia w tym zakresie, postanowiono przyjrzeć się światowej literaturze zagranicznej na ten temat, poczynając od pierwszych poświęconych mu tekstów, które opublikowano w 1982 roku. Celem artykułu jest przybliżenie procesu kształtowania się zainteresowania architekturą informacji na podstawie analizy ilościowej piśmiennictwa dotyczącego tej tematyki, a także wskazanie najważniejszych dla niej autorów i czasopism oraz najczęściej cytowanych publikacji. Ponadto wyszczególnione zostały dyscypliny, w obrębie których najwięcej publikuje się na temat AI i na tym tle sprawdzono stopień zainteresowania tą problematyką w nauce o informacji.

\section{Metodologia}

Cel artykułu wymagał utworzenia możliwie kompletnej bazy danych publikacji dotyczących architektury informacji. Głównymi źródłami danych zostały bazy Web Of Science Core Collection (WoS) i Scopus, które indeksują po kilkanaście tysięcy tytułów czasopism oraz monografie i materiały konferencyjne, ale różnią się zawartością ${ }^{1}$ oraz Proquest Library

\footnotetext{
${ }^{1}$ O różnicach między Scopus a Web of Science pisali m.in. (Chadegani i in., 2013), (Falagas, Pitsouni, Malietzis, \& Pappas, 2008).
} 
and Information Science Abstracts (LISA), będąca jedną z dwóch największych baz bibliograficznych z zakresu nauki o informacji. Opisy bibliograficzne w uwzględnionych bazach, przypisane są do kategorii tematycznych lub dyscyplin, zawierają słowa kluczowe oraz informacje o cytowaniach. Opisy te pozwalają zatem na przeprowadzenie wieloaspektowej analizy ilościowej piśmiennictwa.

Zawartość wybranych baz została przeszukana w dniach 1-2 marca 2019 r. za pomocą terminu ,information architecture”. Przeprowadzono też wyszukiwanie za pomocą terminu "architecture of information”, jednak w wyniku uzyskano zbiór tych samych rekordów, co dla wyszukiwania za pomocą pierwszego terminu, uzupełniony o publikacje dotyczące wyłącznie technicznych aspektów architektury systemów informacyjnych. W bazie WoS termin „information architecture” wyszukiwany był w polu Topic (pole to obejmuje przeszukiwanie tytułu, abstraktu i słów kluczowych). Uzyskano w ten sposób 936 rekordów dokumentów. W bazie Scopus wyszukiwanie objęło pola Title-Abstract-Keywords, a w jego rezultacie otrzymano 1835 rekordów dokumentów. Kwerenda w bazie LISA, wszędzie z wyjątkiem pełnego tekstu (NOFT) dała w wyniku 598 rekordów. Po usunięciu zduplikowanych opisów z trzech baz otrzymano 2269 rekordów dokumentów. W zbiorze tym znalazły się rekordy 20 książek, wśród których zabrakło kilkunastu znanych autorce tytułów, w związku z czym wykonana została oddzielna kwerenda w celu wyszukania wydawnictw zwartych dotyczących analizowanego tematu. Korzystając z wymienionych już baz oraz Google Books, Google Scholar i księgarni internetowej Amazon.com jako źródeł danych, wyszukano w sumie 76 opisów książek.

\section{Analiza literatury z zakresu architektury informacji}

\subsection{Zasoby Scopus, WoS i LISA}

W zbiorze wyszukanych 2269 publikacji dotyczących problematyki AI znalazło się 1100 artykułów z czasopism naukowych i branżowych, 975 tekstów w materiałach konferencyjnych, 174 rozdziały w książkach oraz 20 książek. Dominują dokumenty w języku angielskim. Najstarsze teksty zostały opublikowane w 1982 r., a pierwszy artykuł z „information architecture" w tytule wydany został w 1983 r., co jest zgodne z informacją podaną przez R. León (León, 2014). W tabeli 1 zestawiono liczbę publikacji w kolejnych dekadach, z podziałem na ich rodzaje. Zagadnienia związane z projektowaniem przestrzeni informacyjnych podejmowane są nieprzerwanie od lat 80. XX w., a zainteresowanie tematem wciąż wzrasta.

Tab. 1. Typy publikacji o architekturze informacji w kolejnych dekadach

\begin{tabular}{|l|c|c|c|c|}
\hline & Książki & $\begin{array}{c}\text { Rozdział } \\
\text { w książce }\end{array}$ & $\begin{array}{c}\text { Materiały } \\
\text { konferencyjne }\end{array}$ & $\begin{array}{c}\text { Artykuł } \\
\text { w czasopiśmie }\end{array}$ \\
\hline $1983-1989$ & 0 & 1 & 10 & 17 \\
\hline $1990-1999$ & 1 & 1 & 94 & 105 \\
\hline $2000-2009$ & 7 & 64 & 404 & 459 \\
\hline $2010-2018$ & 12 & 108 & 467 & 519 \\
\hline
\end{tabular}


Wykres na rysunku 1 prezentuje, jak kształtowała się liczba publikacji o architekturze informacji w kolejnych latach z podziałem na ich rodzaje. Do 1999 r. nie przekraczała ona 30 pozycji. Można zauważyć znaczący wzrost liczby dokumentów od 2000 r., wtedy też zaczęły pojawiać się rozdziały poświęcone problematyce AI w książkach. Najwięcej - 145 tekstów, z czego ponad połowę stanowią materiały konferencyjne - wydano w $2013 \mathrm{r}$. Niemal w całym analizowanym okresie wśród form wydawniczych publikacji o AI przeważają artykuły, od 2001 r. publikowano ich minimum 29 rocznie, a najwięcej - 71, w 2012 r. Wyliczenia za 2018 r. mogą nie być pełne, gdyż w marcu 2019 r. część danych mogła jeszcze nie zostać zarejestrowana w bazach, w związku z czym mniejsza liczba publikacji nie musi oznaczać spadającego zainteresowania tematem. Książki publikowane były przede wszystkim w latach 2005-2016, ale nie więcej niż 3 rocznie.

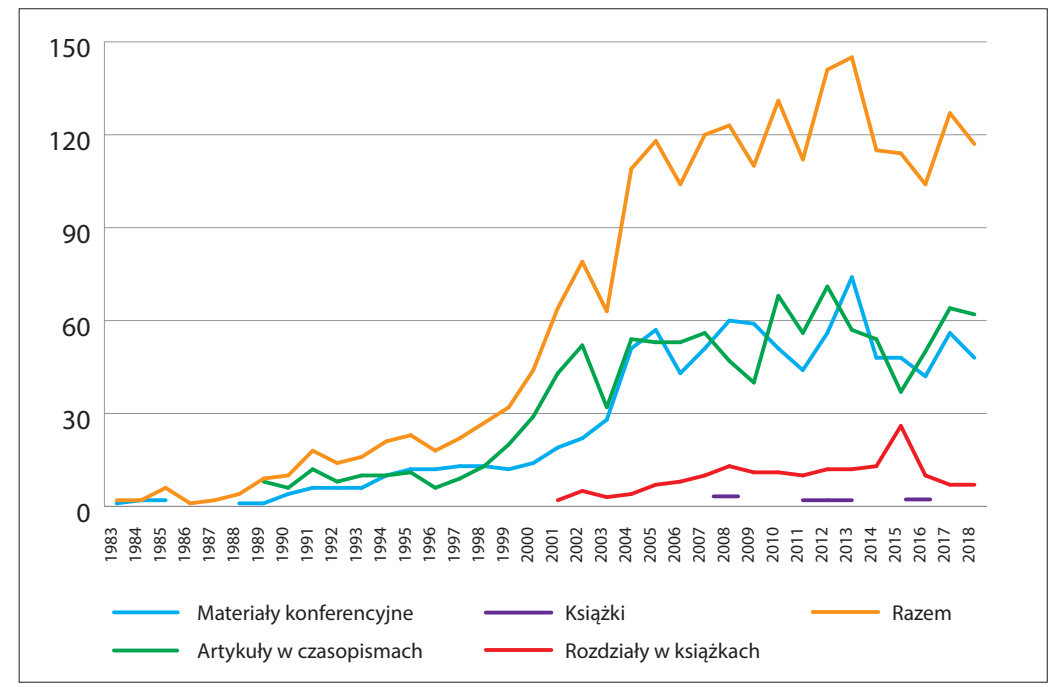

Rys. 1. Liczba publikacji w kolejnych latach

W tabeli 2 znajduje się wykaz 24 autorów wraz z ich afiliacjami, którzy w wyszukanym zbiorze mają więcej niż 5 publikacji. Wśród nich znalazło się ośmiu przedstawicieli krajów europejskich, pięciu ze Stanów Zjednoczonych, po trzech z Australii, Chin i Malezji oraz dwóch z Brazylii. Autorem największej liczby tekstów jest Davide Bolchini. Jest on profesorem w Indiana University School of Informatics and Computing w Stanach Zjednoczonych i pełni funkcję kierownika katedry Human-Centered Computing. Realizuje projekty z zakresu interakcji człowiek-komputer (HCI) i doświadczeń użytkownika (UX). Kolejny z autorów - Marijn Janssen - ma w zbiorze 13 publikacji. Jest on profesorem w Delft University of Technology i kierownikiem sekcji the Information and Communication Technology. Jego zainteresowania koncentrują się na projektowaniu architektury technologii informacyjno-komunikacyjnych wykorzystywanych we współpracy między organizacjami zarówno publicznymi, jak i prywatnymi. Kolejne 11 publikacji jest autorstwa Martina White'a, założyciela Intranet Focus Ltd oraz profesora wizytującego w Information School na Uniwersytecie w Sheffield w Wielkiej Brytanii. Jego prace ukazały się przede wszystkim w magazynie EContent (ISSN: 1525-2531), podejmującym tematykę 
publikowania cyfrowego, mediów i marketingu. W tabeli 2 umieszczono także nazwiska autorów popularnych książek o architekturze informacji: Andrea Resmini i Luci Rosatiego - po osiem ich publikacji znalazło się w analizowanym zbiorze.

Tab. 2. Autorzy, którzy opublikowali najwięcej prac o architekturze informacji

\begin{tabular}{|c|c|c|c|}
\hline Lp. & Autor & Afiliacja & $\begin{array}{c}\text { Liczba } \\
\text { publikacji }\end{array}$ \\
\hline 1 & Bolchini, Davide & Indiana University, Stany Zjednoczone & 16 \\
\hline 2 & Janssen, Marijn & Technische Universiteit Delft, Holandia & 13 \\
\hline 3 & White, Martin & Intranet Focus Ltd, Wielka Brytania & 11 \\
\hline 4 & $\begin{array}{l}\text { Isa, Wan Abdul Rahim } \\
\text { Wan Mohd }\end{array}$ & Universiti Teknologi, Malezja & 10 \\
\hline 5 & Victor E. Sanvido & $\begin{array}{l}\text { Pennsylvania State University, } \\
\text { Stany Zjednoczone }\end{array}$ & 9 \\
\hline 6 & Summers, Tyler & $\begin{array}{l}\text { The University of Texas at Dallas, } \\
\text { Stany Zjednoczone }\end{array}$ & 9 \\
\hline 7 & Garcia, Roberto & Universitat de Lleida, Hiszpania & 8 \\
\hline 8 & Yu, Changbin B & Australian National University, Australia & 8 \\
\hline 9 & Tan, Chekfoung & University of Reading, Wielka Brytania & 8 \\
\hline 10 & Zhang Jinjiang & Zhejiang University, Chiny & 8 \\
\hline 11 & Rosati, Luca & Università per Stranieri di Perugia, Włochy & 8 \\
\hline 12 & Noor, Nor Laila Md & Universiti Teknologi, Malezja & 8 \\
\hline 13 & Resmini, Andrea & Jönköping University, Szwecja & 8 \\
\hline 14 & Anderson, Brian D O & Australian National University, Australia & 8 \\
\hline 15 & Dubey, Abhishek & Vanderbilt University, Stany Zjednoczone & 8 \\
\hline 16 & Lima-Marques, Mamede & Universidade de Brasília, Brazylia & 7 \\
\hline 17 & Karsai, Gabor & Vanderbilt University, Stany Zjednoczone & 7 \\
\hline 18 & Mehad, Shafie & Universiti Teknologi, Malezja & 7 \\
\hline 19 & Rocha, Alvaro & Universidade do Porto, Portugalia & 7 \\
\hline 20 & $\begin{array}{l}\text { Vidotti, Silvana Aparecida } \\
\text { Borsetti Gregorio }\end{array}$ & São Paulo State University, Brazylia & 7 \\
\hline 21 & Brunetti, Josep M & Universitat de Lleida, Hiszpania & 7 \\
\hline 22 & Burford, Sally & University of Canberra, Australia & 7 \\
\hline 23 & Liu Yun & Beijing Institute of Technology, Chiny & 6 \\
\hline 24 & Shieh, Jiann-Cherng & National Taiwan Normal University, Chiny & 6 \\
\hline
\end{tabular}

Tabela 3 zawiera wykaz 21 czasopism, w których opublikowano co najmniej siedem artykułów na temat architektury informacji. Dominują czasopisma amerykańskie (dziewięć tytułów), ponadto jest tam pięć periodyków brytyjskich, trzy brazylijskie, i po jednym z Chin, Hiszpani, Kanady i Kuby. Najwięcej - 25 artykułów - opublikowano w hiszpańskim czasopiśmie Profesional de la Informacion, co stanowi niewiele ponad 2\% wszystkich wyszukanych artykułów. W brazylijskim Informacao E Sociedade-Estudos opublikowano 
21 tekstów. Kolejne czasopismo na liście to wydawany w Stanach Zjednoczonych Journal of the American Society for Information Science and Technology (od 2013 r. ukazuje się pod zmienionym tytułem Journal of the Association for Information Science and Technology). W następnych, także amerykańskich czasopismach na wykazie - EContent oraz Information Today, opublikowano 18 tekstów, a w Technical Communication ukazało się 17 tekstów.

Tab. 3. Czasopisma z największą liczbą artykułów o architekturze informacji

\begin{tabular}{|c|l|c|c|}
\hline Lp. & \multicolumn{1}{|c|}{ Tytuł czasopisma } & ISSN & $\begin{array}{c}\text { Liczba } \\
\text { artykułów }\end{array}$ \\
\hline 1 & Profesional de la Informacion & $1386-6710$ & 25 \\
\hline 2 & Informacao \& Sociedade-Estudos & $0104-0146$ & 21 \\
\hline 3 & $\begin{array}{l}\text { Journal of the American Society for Information Science } \\
\text { and Technology / Journal of the Association for Information } \\
\text { Science and Technology }\end{array}$ & $\begin{array}{c}1532-2882 / \\
2330-1635\end{array}$ & 19 \\
\hline 4 & EContent & $1525-2531$ & 18 \\
\hline 5 & Information Today & $8755-6286$ & 18 \\
\hline 6 & Technical Communication & $0049-3155$ & 17 \\
\hline 7 & $\begin{array}{l}\text { Bulletin of the American Society for Information Science and } \\
\text { Technology }\end{array}$ & $2373-9223$ & 15 \\
\hline 8 & International Journal of Information Management & $0268-4012$ & 11 \\
\hline 9 & $\begin{array}{l}\text { Journal of the China Society for Scientific and Technical } \\
\text { Information }\end{array}$ & $1000-0135$ & 9 \\
\hline 10 & ACIMED & $1024-9435$ & 9 \\
\hline 11 & Online & $0146-5422$ & 9 \\
\hline 12 & Bulletin of the American Society for Information Science & $0095-4403$ & 9 \\
\hline 13 & $\begin{array}{l}\text { Aslib Proceedings / Aslib Journal of Information Manage- } \\
\text { ment }\end{array}$ & $0001-253 X /$ & $2050-3806$ \\
\hline 14 & Journal of Web Librarianship & $1932-2909$ & 8 \\
\hline 15 & Library Hi Tech & $0737-8831$ & 8 \\
\hline 16 & Perspectivas Em Ciencia Da Informacao & $1413-9936$ & 8 \\
\hline 17 & Journal of Medical Internet Research & $1438-8871$ & 7 \\
\hline 18 & Government Information Quarterly & $0740-624 X$ & 7 \\
\hline 19 & Informação \& informação & $0264-0473$ & 7 \\
\hline 20 & The Electronic Library & $0363-0277$ & 7 \\
\hline 21 & Library Journal & & $7981-8920$ \\
\hline
\end{tabular}

Większość tytułów (18) obejmuje swym zakresem naukę o informacji (z czego 15 wyłącznie tę dyscyplinę), trzy podejmują jednocześnie tematykę informatyczną, dwa dotyczą nauk o zdrowiu, a jeden tytuł przypisany jest do zagadnień komunikacji masowej. Spośród periodyków wymienionych $\mathrm{w}$ tabeli $3 \mathrm{w}$ bazie Journal Citation Index jest indeksowanych 14, a 12 z nich przypisanych jest w niej do nauk o informacji i bibliotece, w tym Journal of the American Society for Information Science and Technology i Aslib Proceedings (od 
2014 r. Aslib Journal of Information Management) jednocześnie do informatyki/systemów informacyjnych. Czasopismo Technical Communication reprezentuje jedną dyscyplinę (komunikacja), a Journal of Medical Internet Research opiekę zdrowotną i informatykę medyczną. Zakres tematyczny wymienionych 21 czasopism świadczy o tym, że zagadnienia AI poruszane są w periodykach głównie w obszarze nauki o informacji.

W przeszukiwanych bazach nie było indeksowane czasopismo Journal of Information Architecture $^{2}$ (ISSN 1903-7260), którego redaktorem naczelnym jest Andrea Resmini. Jest ono poświęcone badaniom i rozwojowi architektury informacji we współdzielonych środowiskach informacyjnych z różnych perspektyw - technicznej, kulturowej, społecznej i komunikacyjnej. Jest to półrocznik, w latach 2009-2013³ ukazało się osiem numerów. Razem z artykułami wstępnymi rozpoczynającymi każdy numer, opublikowano w nim łącznie 35 tekstów.

Architektura informacji jest interdyscyplinarna, wśród jej kluczowych obszarów A. Resmini i L. Rosatti wymieniają m.in.: projektowanie informacji, projektowanie wizualne, naukę o informacji i bibliotekoznawstwo, psychologię poznawczą i architekturę (Resmini \& Rosati, 2011, 22). W zbiorze 2269 publikacji znajdują się teksty zróżnicowane tematycznie, dlatego podjęto próbę ustalenia głównych dyscyplin wykorzystując w tym celu klasyfikacje i tematy stosowane w indeksowaniu w bazach stanowiących źródło danych badawczych. Bazy WoS i Scopus, ze względu na rejestrowanie publikacji z zakresu nauk ścisłych, społecznych i humanistycznych, dobrze prezentują przekrój różnych dyscyplin, w obrębie których podejmowana jest tematyka architektury informacji.

Wykres na rysunku 2 przedstawia zestawienie 15 kategorii dziedzinowych Web of Science (Web of Science Categories), do których należy największa liczba publikacji podejmujących tematykę AI. Najliczniej reprezentowana jest kategoria „Nauki komputerowe i systemy informacyjne", w której znalazło się 30\% wyszukanych tekstów; kolejne $25 \%$ piśmiennictwa o AI należy do kategorii „Nauka o informacji i nauka o bibliotece”. Dominują publikacje z zakresu nauk komputerowych (łącznie 765), czyli 84\% całego zbioru wyodrębnionego z WoS przypisanych jest do różnych obszarów informatyki. Należy jednak nadmienić, że jeden dokument może być przypisany do więcej niż jednej kategorii dziedzinowej. Trzy pozostałe kategorie, do których przypisane są publikacje dotyczące problematyki AI, to obszary nauk społecznych: komunikacja (61 publikacji), zarządzanie (54) i biznes (41).

W bazie Scopus każdy dokument ma przypisany co najmniej jeden obszar tematyczny (ang. subject area). Także w tym źródle tematyka architektury informacji związana jest przede wszystkim z naukami ścisłymi. Do obszaru informatyki należą 1092 publikacje, tj. niemal $60 \%$ wyszukanych rekordów. Kolejne licznie reprezentowane kategorie to inżynieria, do której należy 529 dokumentów oraz nauki społeczne (442 dokumenty). Wśród najliczniej reprezentowanych dziedzin znalazły się jeszcze: matematyka (223 rekordy), biznes, zarządzanie i księgowość (153), nauki o decyzjach (119) oraz medycyna (113). Wymienione kategorie tematyczne są bardziej ogólne niż w bazie WoS, dlatego w Scopus dodatkowo analizie poddane zostały słowa kluczowe.

\footnotetext{
${ }^{2}$ Journal of Information Architecture http://journalofia.org/

${ }^{3}$ Z informacji pozyskanych od Jacka Tomaszczyka z bezpośredniej rozmowy z Andreą Resmini, redaktorem naczelnym czasopisma, podczas konferencji Architektura informacji jako dyscyplina akademicka (AIDA Kraków 5-6 czerwca 2018 r.) wiadomo, że czasopismo nie zostało zlikwidowane, ale redakcja nie posiada zasobów ludzkich, czasowych i finansowych, aby je regularnie wydawać, mimo że ma materiał do publikacji.
} 


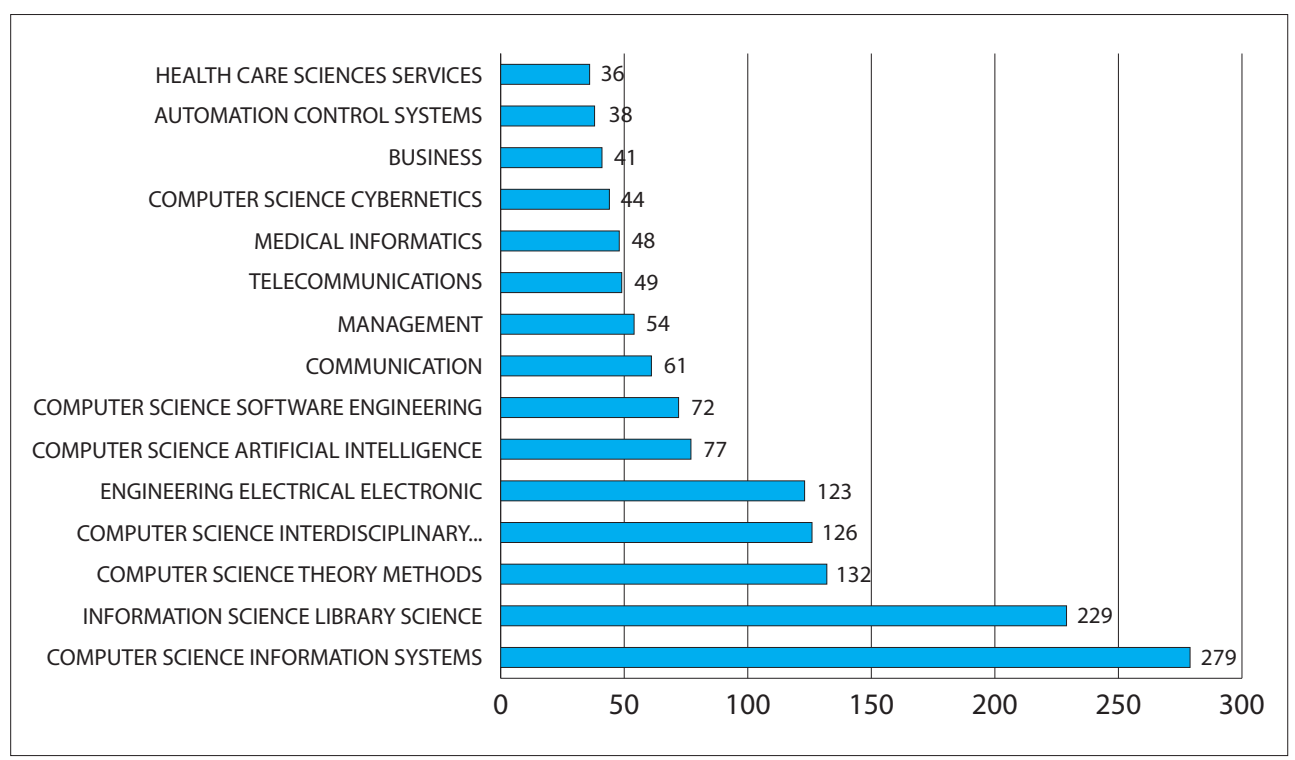

Rys. 2. Kategorie w bazie Web of Science, do których zakwalifikowane są publikacje z zakresu architektury informacji

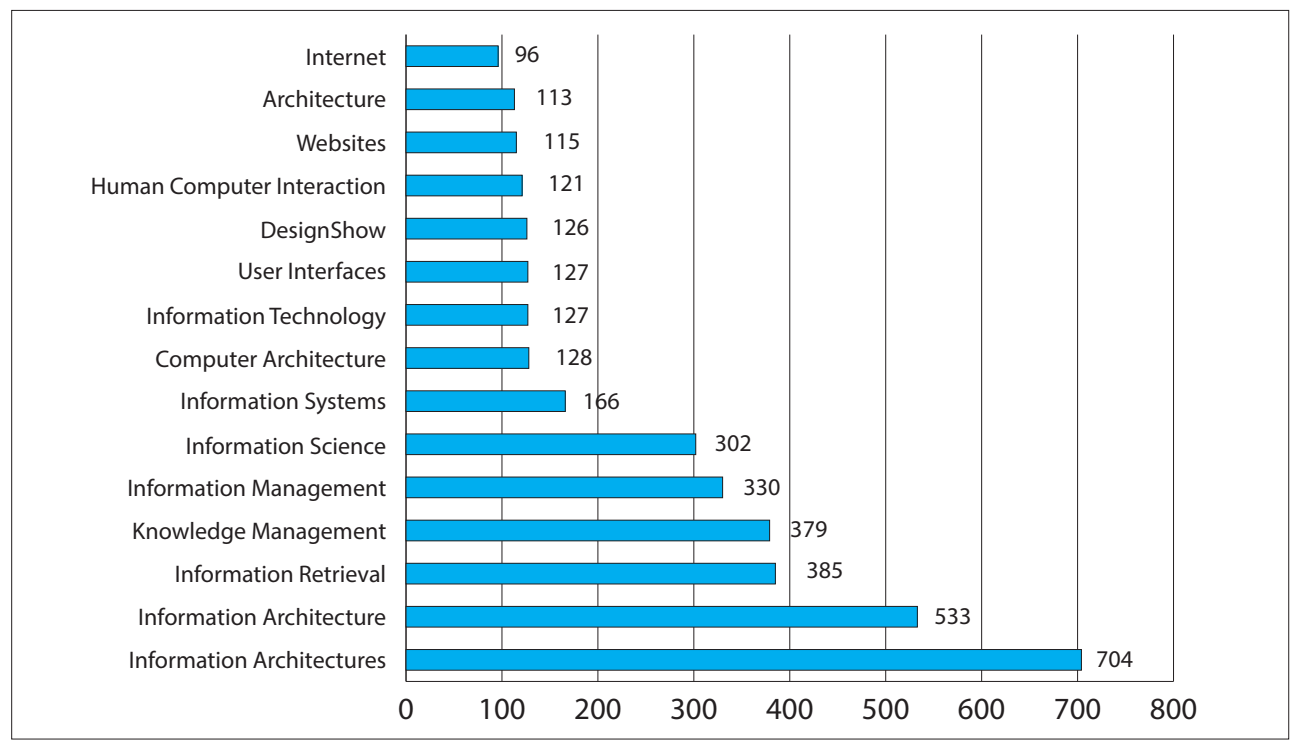

Rys. 3. Słowa kluczowe występujące w bazie Scopus w opisach publikacji dotyczących architektury informacji 
Rysunek 3 przedstawia wykres, w którym zestawiono 15 słów kluczowych najczęściej występujących w indeksowaniu piśmiennictwa o AI. Najwięcej wystąpień zarejestrowano dla dwóch wariantów gramatycznych frazy „information architecture” (704 wystąpienia w liczbie mnogiej i 533 wystąpienia w liczbie pojedynczej). Kolejne cztery słowa kluczowe, występujące więcej niż 300 razy, uznać można za reprezentujące terminologię naukę o informacji: przetwarzanie informacji, zarządzanie wiedzą, zarządzanie informacją, nauka o informacji. Pozostałe słowa kluczowe, chrakteryzujące treść minimum 100 dokumentów, związane są przede wszystkim z technologiami informacyjnymi oraz różnymi aspektami projektowania stron internetowych.

Ze względu na wykazane już związki architektury informacji z nauką o informacji, sprawdzono, czy można dla nich ustalić kluczowe obszary badawcze. W tym celu prześledzono najpopularniejsze tematy w bazie LISA, a 15 najliczniej reprezentowanych wyszczególniono na wykresie (Rys. 4). Najczęściej występującym tematem jest architektura informacji - przypisano jej 36\% publikacji. Kolejne 18\% związane jest z tematyką stron internetowych, a $9 \% \mathrm{z}$ zarządzaniem informacją. Wśród często poruszanych zagadnień znalazło się projektowanie, badania, World Wide Web, systemy informacyjne, czy projektowanie stron internetowych. Liczne są też teksty związane z bibliotekami tradycyjnymi i cyfrowymi, architekturą komputerów i technologią informacyjną, metadanymi oraz użytecznością. Wykaz tematów potwierdza, że w nauce o informacji tematyka AI podejmowana jest w kontekście praktycznym, przede wszystkim projektowania stron WWW i systemów informacyjnych.

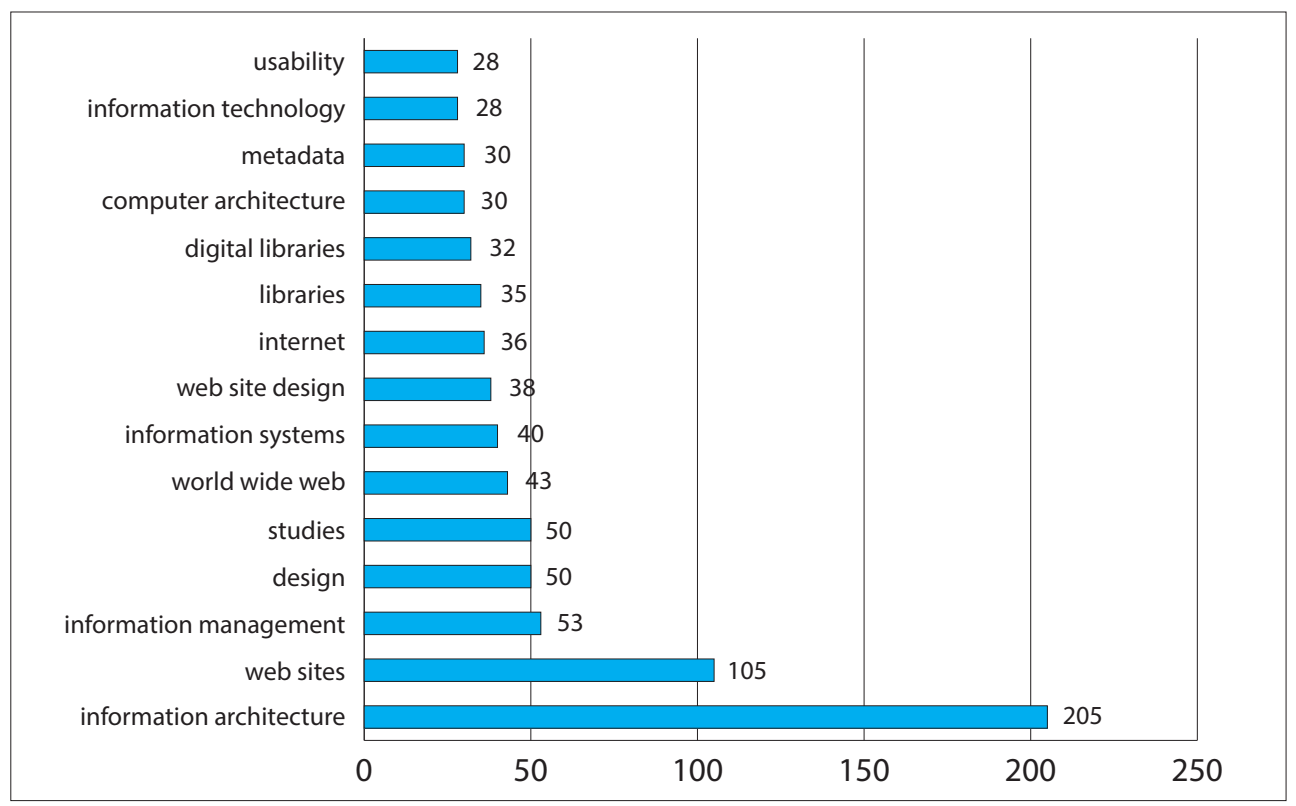

Rys. 4. Tematy publikacji dotyczących architektury informacji, zarejestrowanych w bazie LISA 
Kolejnym aspektem analizy były najczęściej cytowane publikacje. Wyniki ponownie prześledzono oddzielnie dla trzech baz. W tabeli 4 wykazano 19 dokumentów z bazy LISA, które były cytowane co najmniej 10 razy. Większość z nich to artykuły opublikowane w latach 2001-2010. Dwa są z 2012 r., a najnowszy z 2016 r. (czwarte miejsce wśród najczęściej cytowanych). Ich tematyka jest bardzo zróżnicowana. Dwa teksty, na które powoływano się najczęściej, pochodzą z czasopisma z zakresu e-zdrowia. Ponadto wśród najczęściej cytowanych znalazły się artykuły dotyczące: zarządzania bezpieczeństwem informacji, narzędzi wspierających AI (metadane, tezaurusy, itp.), modelowania nawigacji, serwisów zawierających dane i informacje medyczne, czy badań użyteczności stron internetowych bibliotek akademickich.

W tabeli 5 wymienionych jest 20 najczęściej cytowanych dokumentów pochodzących z bazy WoS. W tym źródle odnotowana została znacznie większa liczba powołań. Aż 20 publikacji cytowanych było co najmniej 41 razy. Wynika to przede wszystkim z charakteru bazy, która z założenia jest indeksem cytowań, a nie bazą bibliograficzną. Spośród wyszukanych w WoS dokumentów, 441 pozycji, czyli 47\% wszystkich publikacji cytowane jest co najmniej jeden raz. W sumie zostały one zacytowane 4352 razy. Wśród tekstów, na które powoływano się najczęściej, aż 16 zostało opublikowanych w latach 2000-2009.

Tab. 4. Najczęściej cytowane publikacje dotyczące architektury informacji wg danych bazy LISA

\begin{tabular}{|c|l|c|}
\hline Lp. & \multicolumn{1}{|c|}{ Opis bibliograficzny dokumentu } & $\begin{array}{c}\text { Liczba } \\
\text { cytowań }\end{array}$ \\
\hline 1 & \multicolumn{1}{|c|}{2} & 3 \\
\hline 1 & $\begin{array}{l}\text { Danaher, B. G., McKay, G., Seeley, J. R. (2005). The information architecture of } \\
\text { behavior change Websites. Journal of Medical Internet Research, 7(2). }\end{array}$ & 59 \\
\hline 2 & $\begin{array}{l}\text { McKay, H. G., Danaher, B. G., Seeley, J. R., Lichtenstein, E., Gau, J. M. (2008). } \\
\text { Comparing Two Web-Based Smoking Cessation Programs: Randomized Con- } \\
\text { trolled Trial. Journal of Medical Internet Research, 10(5). }\end{array}$ & 58 \\
\hline 3 & $\begin{array}{l}\text { Hanseth, O., Lyytinen, K. (2010). Design Theory for Dynamic Complexity in } \\
\text { Information Infrastructures: The Case of Building Internet. Journal of Informa- } \\
\text { tion Technology, 25(1), 1-19. }\end{array}$ & 56 \\
\hline 4 & $\begin{array}{l}\text { Soomro, Z. A., Shah, M. H., Ahmed, J. (2016). Information security mana- } \\
\text { gement needs more holistic approach: A literature review. International } \\
\text { Journal of Information Management, 36(2), 215. https://doi.org/10.1016/j. } \\
\text { ijinfomgt.2015.11.009 }\end{array}$ & 33 \\
\hline 5 & $\begin{array}{l}\text { Garshol, L. M. (2004). Metadata? Thesauri? Taxonomies? Topic maps! Making } \\
\text { sense of it all. Journal of Information Science, 30(4), 378-391. }\end{array}$ & 30 \\
\hline 6 & $\begin{array}{l}\text { Miller, C. S., Remington, R. W. (2004). Modeling information navigation: im- } \\
\text { plications for information architecture. Human-Computer Interaction, 19(3), } \\
\text { 225-271. }\end{array}$ & 25 \\
\hline 7 & $\begin{array}{l}\text { Chen, C., Haddad, D., Selsky, J., Hoffman, J. E., Kravitz, R. L., Estrin, D. E., } \\
\text { Sim, I. (2012). Making Sense of Mobile Health Data: An Open Architecture to } \\
\text { Improve Individual - and Population-Level Health. Journal of Medical Internet } \\
\text { Research, 14(4). https://doi.org/10.2196/jmir.2152 }\end{array}$ & $\begin{array}{l}|c| \\
\text { McGillis, L., Toms, E. G. (2001). Usability of the Academic Library Web Site: } \\
\text { Implications for Design. College and Research Libraries, 62(4), 355-367. }\end{array}$ \\
\hline
\end{tabular}




\begin{tabular}{|c|c|c|}
\hline 1 & 2 & 3 \\
\hline 9 & $\begin{array}{l}\text { Pak, R., Price, M. M., Thatcher, J. (2009). Age-Sensitive Design of Online } \\
\text { Health Information: Comparative Usability Study. Journal of Medical Internet } \\
\text { Research, 11(4), 11. https://doi.org/10.2196/jmir.1220 }\end{array}$ & 18 \\
\hline 10 & $\begin{array}{l}\text { Watters, C., Duffy, J., Duffy, K. (2003). Using large tables on small display devi- } \\
\text { ces. International Journal of Human-Computer Studies, 58(1), 21-37. }\end{array}$ & 15 \\
\hline 11 & $\begin{array}{l}\text { Salvo, M. J. (2002). Critical engagement with technology in the computer clas- } \\
\text { sroom. Technical Communication Quarterly, 11(3), 317-337. }\end{array}$ & 13 \\
\hline 12 & $\begin{array}{l}\text { Fisher, L., Bennion, L. (2005). Organizational implications of the future deve- } \\
\text { lopment of technical communication: fostering communities of practice in the } \\
\text { workplace. Technical Communication, 52(3), 277-288. }\end{array}$ & 13 \\
\hline 13 & $\begin{array}{l}\text { van den Haak, M. J., de Jong, M. D. T., Schellens, P. J. (2009). Evaluating Muni- } \\
\text { cipal Websites: A Methodological Comparison of Three Think-Aloud Variants. } \\
\text { Government Information Quarterly, 26(1), 193-202. }\end{array}$ & 13 \\
\hline 14 & $\begin{array}{l}\text { Kees-Jan van Dorp. (2001). Tracking and tracing: A structure for development } \\
\text { and contemporary practices. Logistics Information Management, 15(1/2), } \\
\text { 24-33. }\end{array}$ & 12 \\
\hline 15 & $\begin{array}{l}\text { Pant, S., Ravichandran, T. (2001). A framework for information systems plan- } \\
\text { ning for e-business. Logistics Information Management, 14(1/2), 85-98. }\end{array}$ & 11 \\
\hline 16 & $\begin{array}{l}\text { Iannella, R. (2001). Digital Rights Management (DRM) architectures. D-Lib } \\
\text { Magazine, 7(6). }\end{array}$ & 11 \\
\hline 17 & $\begin{array}{l}\text { Klischewski, R., Scholl, H. J. (2008). Information Quality, as Capstone in Ne- } \\
\text { gotiating e-Government Integration, Interoperation and Information Sharing. } \\
\text { Electronic Government: An International Journal, 5(2), 203-225. }\end{array}$ & 11 \\
\hline 18 & $\begin{array}{l}\text { Savolainen, R., Talja, S., Tuominen, K. (2003). Multiperspective digital libra- } \\
\text { ries: the implications of constructionism for the development of digital libra- } \\
\text { ries. Journal of the American Society for Information Science and Technology, } \\
\text { 54(6), 561-569. }\end{array}$ & 10 \\
\hline 19 & $\begin{array}{l}\text { Yang, T., Linder, J., Bolchini, D. (2012). DEEP: Design-Oriented Evaluation of } \\
\text { Perceived Usability. International Journal of Human-Computer Interaction, } \\
\text { 28(5), 308-346. https://doi.org/10.1080/10447318.2011.586320 }\end{array}$ & 10 \\
\hline
\end{tabular}

Największym zainteresowaniem cieszył się artykuł prezentujący narzędzie do pomiaru elastyczności infrastruktury IT. Kolejny tekst przedstawia rozwiązania z zakresu AI dla zarządzania jakością łańcucha dostaw. A trzecią w wykazie jest jedna ze starszych publikacji, prezentująca architekturę systemów informacyjnych w organizacjach. Powyżej 100 cytowań ma jeszcze artykuł dotyczący analizy logów wyszukiwania i zastosowania wyników tej analizy do projektowania lepszej architektury informacji, interfejsów i systemów informacyjnych.

Tematyka czasopism, z których pochodzą najczęściej cytowane artykuły jest zróżnicowana. Nauki komputerowe reprezentuje 16 tytułów, a nauki społeczne pięć (jedno z czasopism obie dziedziny). Najwięcej artykułów (5) opublikowano w czasopismach z zakresu nauki o informacji, a po cztery w periodykach podejmujących problematykę systemów informacyjnych (informatyka) i informatyki medycznej. W tabeli 5 znalazły się także artykuły, których tematyka została zakwalifikowana do fizjologii, fizyki i biotechnologii, co 
wiąże się z dziedzinową specyfiką systemów i serwisów stanowiących przedmiot analiz. Potwierdza to, że problematyka projektowania przestrzeni informacyjnych jest obecna w różnych dyscyplinach i analizowana w różnych ujęciach. Ogólny trend wskazuje przewagę cytowań tekstów z zakresu nauk komputerowych (informatyki), ale wyraźnie widać obecność nauki o informacji, mimo iż jest to dyscyplina dość wąska, która należąc do nauk humanistycznych i społecznych, jest słabiej reprezentowana w WoS.

Tab. 5. Najczęściej cytowane publikacje o architekturze informacji wg danych Web of Science

\begin{tabular}{|c|c|c|}
\hline Lp. & Opis bibliograficzny dokumentu & $\begin{array}{l}\text { Liczba } \\
\text { cytowań }\end{array}$ \\
\hline 1 & 2 & 3 \\
\hline 1 & $\begin{array}{l}\text { Byrd, T. A., Turner, D. E. (2000). Measuring the flexibility of information } \\
\text { technology infrastructure: Exploratory analysis of a construct. Journal of } \\
\text { Management Information Systems, 17(1), 167-208. }\end{array}$ & 231 \\
\hline 2 & $\begin{array}{l}\text { Xu, L. D. (2011). Information architecture for supply chain quality manage- } \\
\text { ment. International Journal of Production Research, 49(1), 183-198. https:// } \\
\text { doi.org/10.1080/00207543.2010.508944 }\end{array}$ & 152 \\
\hline 3 & $\begin{array}{l}\text { Allen, B. R., Boynton, A. C. (1991). Information architecture - in search of } \\
\text { efficient flexibility. MIS quarterly: management information systems., 15(4), } \\
\text { 435-445. https://doi.org/10.2307/249447 }\end{array}$ & 109 \\
\hline 4 & $\begin{array}{l}\text { Jansen, B. J. (2006). Search log analysis: What it is, what's been done, how } \\
\text { to do it. Library E information science research, 28(3), 407-432. https://doi. } \\
\text { org/10.1016/j.lisr.2006.06.005 }\end{array}$ & 101 \\
\hline 5 & $\begin{array}{l}\text { Marceglia, S., Foffani, G., Bianchi, A. M., Baselli, G., Tamma, F., Egidi, M., } \\
\text { Priori, A. (2006). Dopamine-dependent non-linear correlation between } \\
\text { subthalamic rhythms in Parkinson's disease. Journal of Physiology-London, } \\
\text { 571(3), 579-591. https://doi.org/10.1113/jphysiol.2005.100271 }\end{array}$ & 97 \\
\hline 6 & $\begin{array}{l}\text { Garshol, L. M. (2004). Metadata? Thesauri? Taxonomies? Topic maps! Ma- } \\
\text { king sense of it all. Journal of Information Science, 30(4), 378-391. }\end{array}$ & 91 \\
\hline 7 & $\begin{array}{l}\text { Hucul, D., Inlek, I. V., Vittorini, G., Crocker, C., Debnath, S., Clark, S. M., } \\
\text { Monroe, C. (2015). Modular entanglement of atomic qubits using pho- } \\
\text { tons and phonons. Nature physics, 11(1), 37-42. https://doi.org/10.1038/ } \\
\text { nphys3150 }\end{array}$ & 90 \\
\hline 8 & $\begin{array}{l}\text { Byrd, T. A., Turner, D. E. (2001). An exploratory examination of the re- } \\
\text { lationship between flexible IT infrastructure and competitive advantage. } \\
\text { Information E Management, 39(1), 41-52. https://doi.org/10.1016/s0378- } \\
\text { 7206(01)00078-7 }\end{array}$ & 89 \\
\hline 9 & $\begin{array}{l}\text { Summers, T. H., Akella, M. R., Mears, M. J. (2009). Coordinated Standoff } \\
\text { Tracking of Moving Targets: Control Laws and Information Architectures. } \\
\text { Journal of guidance, control, and dynamics: a publication of the American In- } \\
\text { stitute of Aeronautics and Astronautics devoted to the technology of dynamics } \\
\text { and control, 32(1), 56-69. https://doi.org/10.2514/1.37212 }\end{array}$ & 84 \\
\hline 10 & $\begin{array}{l}\text { McKay, H. G., Danaher, B. G., Seeley, J. R., Lichtenstein, E., Gau, J. M. (2008). } \\
\text { Comparing Two Web-Based Smoking Cessation Programs: Randomized } \\
\text { Controlled Trial. Journal of Medical Internet Research, 10(5). }\end{array}$ & 73 \\
\hline
\end{tabular}




\begin{tabular}{|c|c|c|}
\hline 1 & 2 & 3 \\
\hline 11 & $\begin{array}{l}\text { Stead, W. W., Miller, R. A., Musen, M. A., Hersh, W. R. (2000). Integration } \\
\text { and beyond: Linking information from disparate sources and into work- } \\
\text { flow. Journal of the American Medical Informatics Association: JAMIA, 7(2), } \\
\text { 135-145. https://doi.org/10.1136/jamia.2000.0070135 }\end{array}$ & 70 \\
\hline 12 & $\begin{array}{l}\text { Large, A., Beheshti, J., Rahman, T. (2002). Design criteria for children's web } \\
\text { portals: the users speak out. Journal of the American Society for Information } \\
\text { Science and Technology, 53(2), 79-94. }\end{array}$ & 68 \\
\hline 13 & $\begin{array}{l}\text { Danaher, B. G., McKay, G., Seeley, J. R. (2005). The information architecture } \\
\text { of behavior change Websites. Journal of Medical Internet Research, 7(2). }\end{array}$ & 68 \\
\hline 14 & $\begin{array}{l}\text { Hoogervorst, J. (2004). Enterprise architecture: Enabling integration, agility } \\
\text { and change. International Journal of Cooperative Information Systems, 13(3), } \\
\text { 213-233. https://doi.org/10.1142/s021884300400095x }\end{array}$ & 60 \\
\hline 15 & $\begin{array}{l}\text { McGillis, L., Toms, E. G. (2001). Usability of the Academic Library Web Site: } \\
\text { Implications for Design. College and Research Libraries, 62(4), 355-367. }\end{array}$ & 57 \\
\hline 16 & $\begin{array}{l}\text { Richardson, G. L., Jackson, B. M., Dickson, G. W. (1990). A principles-ba- } \\
\text { sed enterprise architecture - lessons from texaco and star enterprise. MIS } \\
\text { quarterly: management information systems., 14(4), 385-403. https://doi. } \\
\text { org/10.2307/249787 }\end{array}$ & 56 \\
\hline 17 & $\begin{array}{l}\text { Yasnoff, W. A., Overhage, J. M., Humphreys, B. L., LaVenture, M. (2001). } \\
\text { A national agenda for public health informatics: Summarized recommenda- } \\
\text { tions from the } 2001 \text { AMIA Spring Congress. Journal of the American Medical } \\
\text { Informatics Association: JAMIA, 8(6), 535-545. https://doi.org/10.1136/ } \\
\text { jamia.2001.0080535 }\end{array}$ & 53 \\
\hline 18 & $\begin{array}{l}\text { Seringhaus, M. R., Gerstein, M. B. (2007). Publishing perishing? Towards } \\
\text { tomorrow's information architecture. BMC bioinformatics, } 8 \text {, 5. https://doi. } \\
\text { org/10.1186/1471-2105-8-17 }\end{array}$ & 45 \\
\hline 19 & $\begin{array}{l}\text { Shen, W. M., Lang, S. Y. T., Wang, L. H. (2005). iShopfloor: An Internet-ena- } \\
\text { bled agent-based intelligent shop floor. Ieee Transactions on Systems Man } \\
\text { and Cybernetics Part C-Applications and Reviews, 35(3), 371-381. https:// } \\
\text { doi.org/10.1109/tsmcc.2004.843224 }\end{array}$ & 44 \\
\hline 20 & $\begin{array}{l}\text { Miller, C. S., Remington, R. W. (2004). Modeling information navigation: } \\
\text { implications for information architecture. Human-Computer Interaction, } \\
\text { 19(3), 225-271. }\end{array}$ & 41 \\
\hline
\end{tabular}

Aby dać pełniejszy obraz cytowań dokumentów dotyczących architektury informacji, prześledzono również dane z bazy Scopus. Tutaj odnotowano ich jeszcze więcej niż w opisanych już bazach. Publikacje w niej wyszukane, począwszy od 1988 r., zacytowane zostały 12564 razy. Spośród 1836 dokumentów 58\%, czyli 1076 publikacji zacytowano co najmniej raz. W tabeli 6 znajduje się wykaz 20 najczęściej cytowanych publikacji, wśród których tylko jedna ma mniej niż 100 cytowań. Wśród tekstów, na które powoływano się najczęściej, 13 zostało opublikowanych w latach 2000-2009. Najwięcej cytowań ma artykuł, który ukazał się w 1991 r. w czasopiśmie Harvard Business Review. Dotyczy on możliwości wykorzystania nowych technologii do pomiaru niefinansowych działań firmy, w tym opracowania architektury informacji serwisu realizującego taki pomiar. Najczęściej cytowany artykuł dotyczący AI i zarejestrowany w bazie WoS w zestawianiu danych z bazy 
Scopus znalazł się na miejscu drugim, ale tutaj odnotowano niemal dwukrotnie więcej jego powołań. Kolejny tekst, z liczbą 317 powołań, opublikowany został w czasopiśmie Science. Traktuje on o nowych rozwiązaniach w architekturze informacji systemów zorientowanych na usługi, umożliwiających projektowanie interfejsów i protokołów do publikowania i dostępu do cennych danych i programów w nauce nie tylko specjalistom. Najczęściej cytowane są artykuły z czasopism naukowych, ale w wykazie znalazły się też cztery teksty opublikowane w materiałach konferencyjnych oraz jedna książka.

Tab. 6. Najczęściej cytowane dokumenty o architekturze informacji wg danych bazy Scopus

\begin{tabular}{|c|c|c|}
\hline Lp. & Opis bibliograficzny dokumentu & $\begin{array}{c}\text { Liczba } \\
\text { cytowań }\end{array}$ \\
\hline 1 & 2 & 3 \\
\hline 1 & $\begin{array}{l}\text { Eccles, R. G. (1991). The performance measurement manifesto. Harvard } \\
\text { Business Review, 69(1), 131-137. }\end{array}$ & 653 \\
\hline 2 & $\begin{array}{l}\text { Byrd, T. A., Turner, D. E. (2000). Measuring the flexibility of information } \\
\text { technology infrastructure: Exploratory analysis of a construct. Journal of } \\
\text { Management Information Systems, 17(1), 167-208. }\end{array}$ & 405 \\
\hline 3 & $\begin{array}{l}\text { Foster, I. (2005). Service-oriented science. Science, 308(5723), 814-817. } \\
\text { https://doi.org/10.1126/science.1110411 }\end{array}$ & 317 \\
\hline 4 & $\begin{array}{l}\text { Geerts, G. L., McCarthy, W. E. (2002). An ontological analysis of the eco- } \\
\text { nomic primitives of the extended-REA enterprise information architecture. } \\
\text { International Journal of Accounting Information Systems, 3(1), 1-16. } \\
\text { https://doi.org/10.1016/S1467-0895(01)00020-3 }\end{array}$ & 175 \\
\hline 5 & $\begin{array}{l}\text { Xu, L. D. (2011). Information architecture for supply chain quality manage- } \\
\text { ment. International Journal of Production Research, 49(1), 183-198. } \\
\text { https://doi.org/10.1080/00207543.2010.508944 }\end{array}$ & 174 \\
\hline 6 & $\begin{array}{l}\text { Jarvenpaa, S. L., Ives, B. (1993). The global network organization of the future: } \\
\text { Information management opportunities and challenges. Journal of Manage- } \\
\text { ment Information Systems, 10(3), 25-57. }\end{array}$ & 173 \\
\hline 7 & $\begin{array}{l}\text { Allen, B. R., Boynton, A. C. (1991). Information architecture - in search of } \\
\text { efficient flexibility. MIS quarterly: management information systems., 15(4), } \\
\text { 435-445. https://doi.org/10.2307/249447 }\end{array}$ & 172 \\
\hline 8 & $\begin{array}{l}\text { Jansen, B. J. (2006). Search log analysis: What it is, what's been done, how to } \\
\text { do it. Library E information science research, 28(3), 407-432. } \\
\text { https://doi.org/10.1016/j.lisr.2006.06.005 }\end{array}$ & 160 \\
\hline 9 & $\begin{array}{l}\text { Qin, Z., Denker, G., Giannelli, C., Bellavista, P., Venkatasubramanian, N. } \\
\text { (2014). A software defined networking architecture for the internet-of-things. } \\
\text { W IEEE/IFIP NOMS 2014 - IEEE/IFIP Network Operations and Manage- } \\
\text { ment Symposium: Management in a Software Defined World. IEEE Computer } \\
\text { Society. https://doi.org/10.1109/NOMS.2014.6838365 }\end{array}$ & 157 \\
\hline 10 & $\begin{array}{l}\text { Byrd, T. A., Turner, D. E. (2001). An exploratory examination of the re- } \\
\text { lationship between flexible IT infrastructure and competitive advantage. } \\
\text { Information E Management, 39(1), 41-52. https://doi.org/10.1016/s0378- } \\
\text { 7206(01)00078-7 }\end{array}$ & 150 \\
\hline
\end{tabular}




\begin{tabular}{|c|c|c|}
\hline 1 & 2 & 3 \\
\hline 11 & $\begin{array}{l}\text { Newman, M. W., Landay, J. A. (2000). Sitemaps, storyboards, and specifica- } \\
\text { tions: A sketch of web site design practice. Proceedings of the Conference on } \\
\text { Designing Interactive Systems: Processes, Practices, Methods, and Techniques } \\
\text { (DIS 2000), 263-274. }\end{array}$ & 128 \\
\hline 12 & $\begin{array}{l}\text { Summers, T. H., Akella, M. R., Mears, M. J. (2009). Coordinated standoff trac- } \\
\text { king of moving targets: Control laws and information architectures. Journal } \\
\text { of Guidance, Control, and Dynamics, 32(1), 56-69. } \\
\text { https://doi.org/10.2514/1.37212 }\end{array}$ & 126 \\
\hline 13 & $\begin{array}{l}\text { Weber, R. H., Weber, R. (2010). Internet of things: Legal perspectives. Springer } \\
\text { Berlin Heidelberg. https://doi.org/10.1007/978-3-642-11710-7 }\end{array}$ & 123 \\
\hline 14 & $\begin{array}{l}\text { Klemmer, S. R., Newman, M. W., Farrell, R., Bilezikjian, M., Landay, J. A. } \\
\text { (2001). The Designers' Outpost: A tangible interface for collaborative web site } \\
\text { design. W UIST (User Interface Software and Technology): Proceedings of the } \\
\text { ACM Symposium (1-10). }\end{array}$ & 123 \\
\hline 15 & $\begin{array}{l}\text { Arsanjani, A., Zhang, L.-J., Ellis, M., Allam, A., Channabasavaiah, K. (2007). } \\
\text { S3: A service-oriented reference architecture. IT Professional, 9(3), 10-17. } \\
\text { https://doi.org/10.1109/MITP.2007.53 }\end{array}$ & 117 \\
\hline 16 & $\begin{array}{l}\text { Richardson, G. L., Jackson, B. M., Dickson, G. W. (1990). A principles-based } \\
\text { enterprise architecture - lessons from texaco and star enterprise. MIS quar- } \\
\text { terly: management information systems., 14(4), 385-403. } \\
\text { https://doi.org/10.2307/249787 }\end{array}$ & 114 \\
\hline 17 & $\begin{array}{l}\text { Marceglia, S., Foffani, G., Bianchi, A. M., Baselli, G., Tamma, F., Egidi, M., } \\
\text { Priori, A. (2006). Dopamine-dependent non-linear correlation between } \\
\text { subthalamic rhythms in Parkinson's disease. Journal of Physiology-London, } \\
\text { 571(3), 579-591. https://doi.org/10.1113/jphysiol.2005.100271 }\end{array}$ & 101 \\
\hline 18 & $\begin{array}{l}\text { Garshol, L. M. (2004). Metadata? Thesauri? Taxonomies? Topic maps! Making } \\
\text { sense of it all. Journal of Information Science, 30(4), 378-391. }\end{array}$ & 101 \\
\hline 19 & $\begin{array}{l}\text { Large, A., Beheshti, J., Rahman, T. (2002). Design criteria for children's web } \\
\text { portals: the users speak out. Journal of the American Society for Information } \\
\text { Science and Technology, 53(2), 79-94. }\end{array}$ & 100 \\
\hline 20 & $\begin{array}{l}\text { Kim, Y., Schmid, T., Charbiwala, Z. M., Friedman, J., Srivastava, M. B. (2008). } \\
\text { NAWMS: Nonintrusive autonomous water monitoring system. W Sen- } \\
\text { Sys'08 - Proceedings of the 6th ACM Conference on Embedded Networked } \\
\text { Sensor Systems (s. 309-321). https://doi.org/10.1145/1460412.1460443 }\end{array}$ & 97 \\
\hline
\end{tabular}

Po porównaniu danych umieszczonych w tabelach 4, 5 i 6, znaleziono dziewięć publikacji powtarzających się wśród najczęściej cytowanych w Scopus i Web of Science. Jeden z tych artykułów, publikacja Larsa M. Garshola (2004), wystąpił się we wszystkich trzech tabelach, z liczbą 101 cytowań w Scopus, 91 w WoS i 30 w LISA. Prezentuje on tradycyjne narzędzia nauki o informacji, jak metadane, tezaurusy, taksonomie i mapy tematyczne, które jako niewidoczne elementy wspierają architekturę informacji.

Wykres na rysunku 5 prezentuje liczbę cytowań piśmiennictwa o AI wg danych baz Scopus i Web of Science - od pierwszego, odnotowanego w 1985 r., przez kolejne dwa cytowania, które wystąpiły w 1987 r., do 2018 r. Według danych z bazy Scopus, liczba 
powołań stopniowo zwiększała się od 1988 r., a znaczny ich wzrost, powyżej 100 cytowań, można zaobserwować od 2000 r. Najwięcej cytowań (1151) odnotowano w tej bazie dla 2018 r. W bazie WoS, pierwsze cytowanie pojawiło się w 1987 r., w latach 1988-1990 nie było powołań na teksty z badanego tematu, ale później następował systematyczny wzrost aż do 445 w 2017 r. Niewielki spadek cytowań w tej bazie, zauważalny za 2018 r., może być uzasadniony tym, że zestaw danych za ostatni rok mógł być niekompletny w momencie pisania tego artykułu. Wykres pokazuje stale rosnące zainteresowanie publikacjami z zakresu architektury informacji, odnotowane dla obu źródeł.

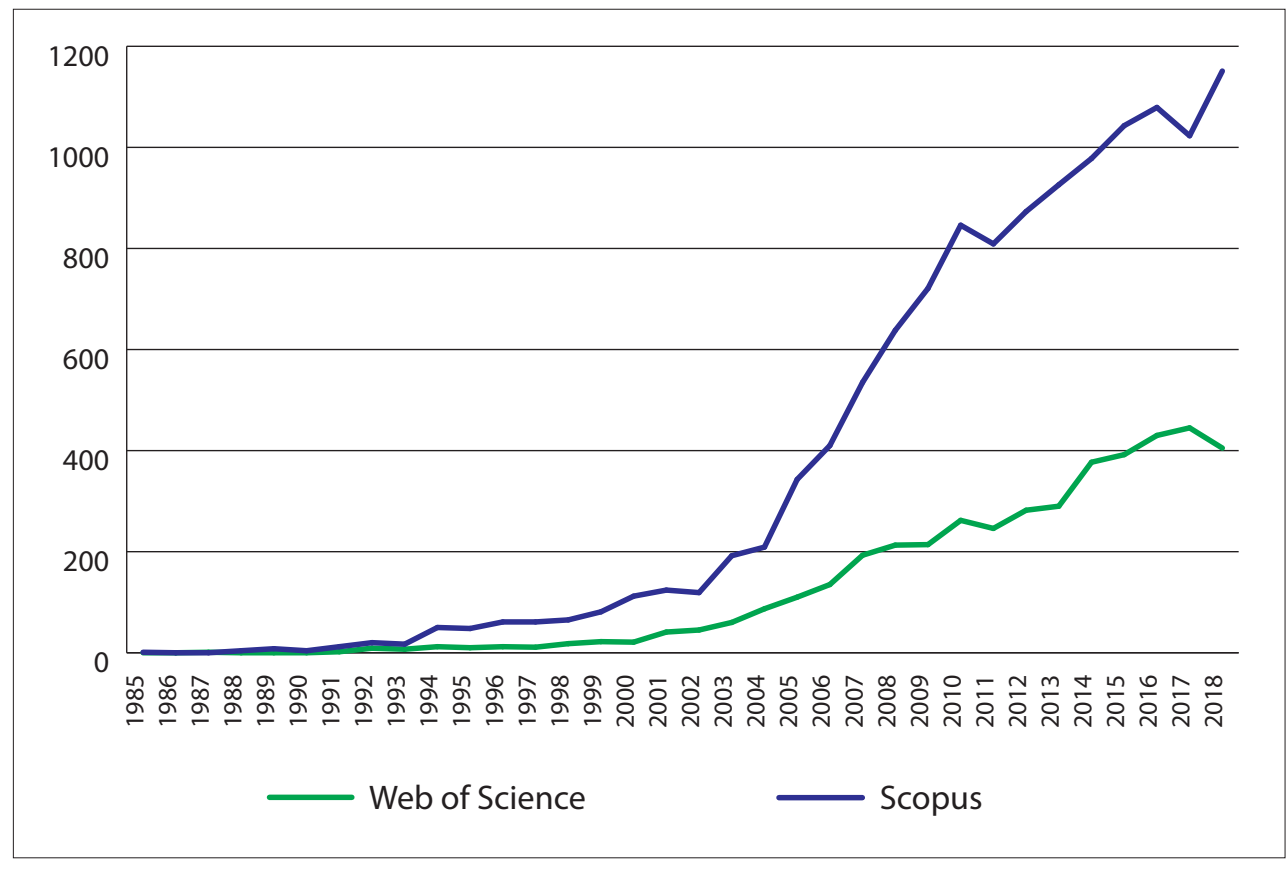

Rys. 5. Rozkład chronologiczny cytowań publikacji dotyczących architektury informacji w bazach Scopus i Web of Science

\subsection{Ksiażki z zakresu architektury informacji}

Gromadząc dane do tej części artykułu, poza książkami znalezionymi w bazie Scopus, skupiono się na poszukiwaniu wydawnictw zwartych, w których tytule, opisie lub w spisie treści występował termin „architektura informacji” (ang. information architecture). Pominięte zostały książki z zakresu User Experience i User Intereface Design, gdyż tematyka ta nie była obecna w pierwszej części badania. Wykaz 76 wyselekcjonowanych publikacji znajduje się w załączniku 1. Zestawiając je z liczbą wszystkich publikacji, stanowią one 3\% zgromadzonej przez autorkę literatury. Pierwsza książka w wykazie (Cook \& Books, 1996) została wydana w 1996 r., rok później R.S. Wurman zdefniował zadania architektów informacji (Wurman, 1997), a w 1998 r. wydana została jedna z najbardziej znanych książek dotyczących architektury informacji (Morville \& Rosenfeld, 1998). 
Rysunek 6 prezentuje chronologiczny rozkład publikacji książek dotyczących architektury informacji. Poza latami 2001 i 2004 ukazywała się co najmniej jedna książka rocznie, a najwięcej, po osiem tytułów, wydano w 2010 i 2015 r. Kilka publikacji doczekało się kolejnych wydań. Najwięcej, bo aż cztery wydania ma Information Architecture for the World Wide Web: Designing Large-Scale Web Sites (Morville \& Rosenfeld, 1998, 2002, 2006), ale ostatnie wydanie, najbardziej zmienione, przygotowane zostało z trzecim współautorem i ukazało się pod zmodyfikowanym tytułem Information Architecture: For the Web and Beyond (Rosenfeld et al., 2015). Trzy inne książki miały po dwa wydania. Kilku autorów opublikowało więcej niż jedną książkę. Uwzględniając wszystkie wydania, zauważyć można, że najbardziej aktywnymi autorami publikacji książkowych są: Peter Morville (sześć książek), Louis Rosenfeld (pięć książek) oraz Gerard Blokdyk (cztery książki). Po dwie książki wydali: Jorge Arango, Dan Brown, Wei Ding, Xia Lin, Andrea Resmini, Donna Spencer i Christina Wodtke.

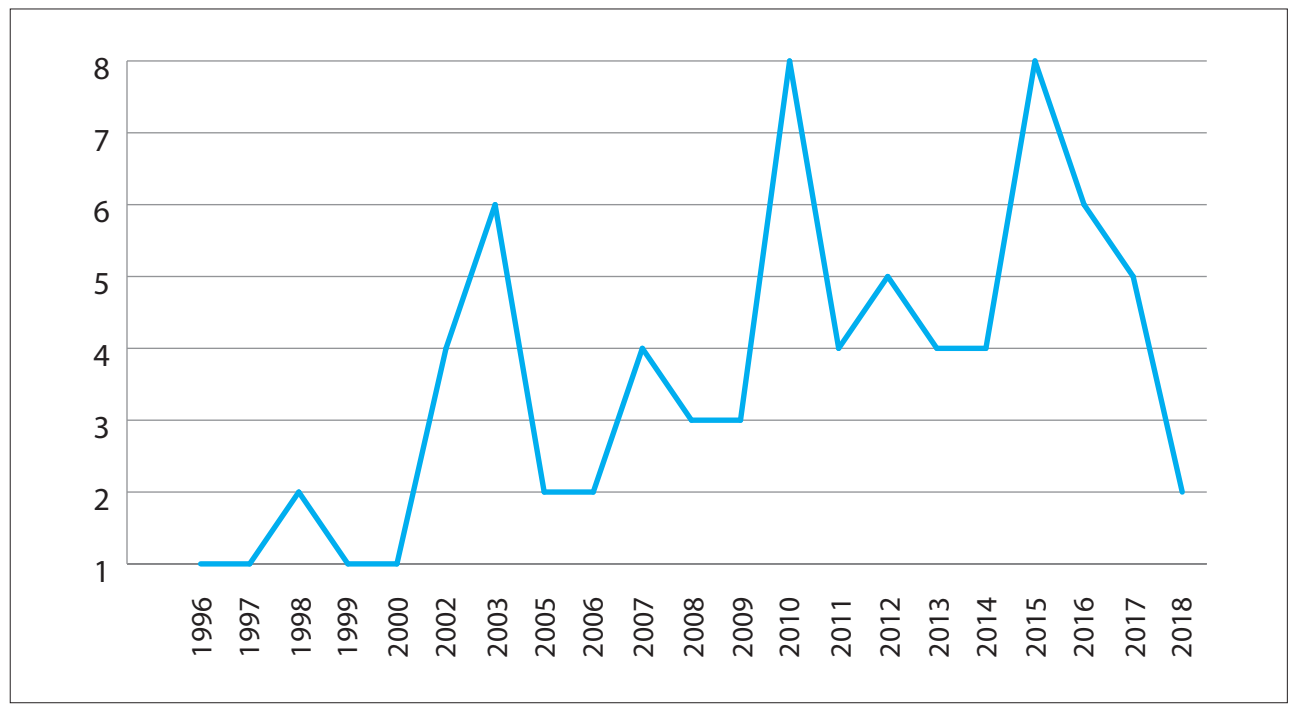

Rys. 6. Chronologiczny rozkład publikacji książek na temat architektury informacji

Ostatnią z interesujących kwestii dotyczących wydawnictw zwartych była próba oceny ich popularności mierzona liczbą cytowań. W tym celu każda książka została sprawdzona w Google Scholar (GS), gdyż było to jedyne źródło indeksujące większość zgromadzonych tytułów. Cytowania dla kilku wydań tego samego tytułu zostały zsumowane, gdyż wybrane narzędzie nie uwzględniało oddzielnych danych dla różnych wydań. Spośród 76 książek, dziewięć nie zostało zaindeksowanych przez GS, a pięć tytułów nie miało cytowań. Pozostałe publikacje miały minimum po dwa powołania. Łącznie książki zacytowano 9078 razy, co stanowi tylko o 1/4 mniej niż liczba wszystkich cytowań piśmiennictwa o AI zarejestrowanych w bazie Scopus i dwa razy więcej niż suma cytowań wykazywanych dla tego piśmiennictwa w Web of Science. Najwięcej, 3128 cytowań, ma książka Information Architecture for the World Wide Web: Designing Large-Scale Web Sites (Morville \& Rosenfeld, 1998 i kolejne dwa wydania), na czwarte wydanie od 2015 r. powoływano się 147 razy. Pierwsza dziesiątka najczęściej cytowanych książek przedstawiona jest w tabeli 7 
(w opisach uwzględniono pierwsze wydanie). Jak widać, dwie najczęściej cytowane prace są autorstwa lub współautorstwa P. Morville’a. Z liczbą przekraczającą 500 cytowań jest książka dotycząca badań użyteczności - technik gromadzenia informacji o wymaganiach użytkowników w projektowaniu produktów cyfrowych. W tabeli znajduje się wspomniana już wcześniej książka R. S. Wurmana o architektach informacji. W wykazie są również publikacje dotyczące architektury systemów informacyjnych przedsiębiorstw oraz książki o charakterze bardziej praktycznym, przedstawiające metodę sortowania kart, projektowania nawigacji czy tworzenia użytecznych treści dla użytkowników Internetu, a jeden z tytułów poświęcony jest perspektywom prawnym Internetu Rzeczy.

Tab. 7. Najczęściej cytowane książki

\begin{tabular}{|c|c|c|}
\hline Lp. & Opis książki & $\begin{array}{l}\text { Liczba } \\
\text { cytowań }\end{array}$ \\
\hline 1 & $\begin{array}{l}\text { Morville, P., Rosenfeld, L. (1998). Information Architecture for the World Wide } \\
\text { Web: Designing Large-scale Web Sites (1 edition). Cambridge ; Sebastopol, CA: } \\
\text { O'Reilly Media. }\end{array}$ & 3078 \\
\hline 2 & $\begin{array}{l}\text { Morville, P. (2005). Ambient Findability: What We Find Changes Who We Beco- } \\
\text { me (1 edition). Beijing ; Sebastopol, CA: O'Reilly Media. }\end{array}$ & 833 \\
\hline 3 & $\begin{array}{l}\text { Courage, C., Baxter, K. (2005). Understanding Your Users. A Practical Guide } \\
\text { to User Requirements: Methods, Tools, and Techniques. Amsterdam: Elsevier. } \\
\text { https://doi.org/10.1016/B978-1-55860-935-8.X5029-5 }\end{array}$ & 525 \\
\hline 4 & Wurman, R. S. (1997). Information Architects (First Edition). Zürich: Graphis Inc. & 487 \\
\hline 5 & $\begin{array}{l}\text { Cook, M., Books, H.-P. P. (1996). Building Enterprise Information Architectures: } \\
\text { Reengineering Information Systems (1 edition). Upper Saddle River, NJ: Prentice } \\
\text { Hall. }\end{array}$ & 309 \\
\hline 6 & $\begin{array}{l}\text { Minoli, D. (2008). Enterprise Architecture A to Z: Frameworks, Business Process } \\
\text { Modeling, SOA, and Infrastructure Technology. Boca Raton: Auerbach Publica- } \\
\text { tions. https://doi.org/10.1201/9781420013702 }\end{array}$ & 285 \\
\hline 7 & $\begin{array}{l}\text { Weber, R. H., Weber, R. (2010). Internet of things: Legal perspectives. Springer } \\
\text { Berlin Heidelberg. https://doi.org/10.1007/978-3-642-11710-7 }\end{array}$ & 284 \\
\hline 8 & $\begin{array}{l}\text { Spencer, D. (2009). Card Sorting: Designing Usable Categories (1 edition). } \\
\text { Rosenfeld Media. }\end{array}$ & 264 \\
\hline 9 & $\begin{array}{l}\text { Kalbach, J. (2007). Designing Web navigation (1st ed). Beijing ; Sebastopol: } \\
\text { O'Reilly. }\end{array}$ & 249 \\
\hline 10 & $\begin{array}{l}\text { Redish, J. G. (2007). Letting Go of the Words. Elsevier Inc. https://doi. } \\
\text { org/10.1016/B978-0-12-369486-7.X5000-9 }\end{array}$ & 204 \\
\hline
\end{tabular}

\section{Zakończenie}

Architektura informacji jest młodą dyscypliną. Pierwsze publikacje dotyczące tego tematu pochodzą z 1982 r., a w tytule termin „information architecture” po raz pierwszy użyty został w 1983 r. Od 2000 r. obserwuje się rosnące zainteresowanie problematyką AI znacząco wzrosła liczba poświęconych jej publikacji, artykułów w czasopismach i tekstów 
w materiałach konferencyjnych. Także liczba cytowań publikacji z tego zakresu z roku na rok jest większa. Mimo iż w świetle zgromadzonych danych książki stanowią zaledwie 3\% piśmiennictwa o AI, to liczba ich cytowań wskazuje na ich intensywne wykorzystywanie przez kolejnych autorów. Zainteresowanie jest globalne, nie można ustalić kluczowych ośrodków prowadzących badania w zakresie architektury informacji, autorzy są z całego świata, a pod względem liczby publikacji wyróżniają się przede wszystkim: Davide Bolchini, Marijn Janssen i Martin White. Biorąc pod uwagę liczbę książek, jako najbardziej produktywnych autorów należy wskazać: Petera Morville’a, Gerarda Blokdyka i Luisa Rosenfelda. W badaniu ustalono zaledwie osiem periodyków, w których opublikowano więcej niż 10 artykułów dotyczących AI. Poza kilkoma numerami Journal of Information Architecture (ukazującego się regularnie w latach 2009-2013), nie ma wiodącego czasopisma poświęconego temu tematowi. Dominują czasopisma z nauki o informacji, systemów informacyjnych (informatyka) i komunikacji, co potwierdza szerokie, interdyscyplinarne zainteresowanie problematyką projektowania przestrzeni informacyjnych. Z kolei materiały konferencyjne prezentują przede wszystkim aspekty informatyczne AI. Wśród najczęściej cytowanych artykułów przeważają publikacje z czasopism informatycznych, ale licznie reprezentowane są też czasopisma z nauki o informacji. Analiza literatury zgromadzonej w omówionych badaniach nie wykazała związków AI z architekturą, projektowaniem wizualnym czy psychologią. Zebrane piśmiennictwo reprezentuje przede wszystkim architekturę informacji jako przedmiot informatyki (badań nad systemami informacyjnymi), inżynierii oraz nauki o informacji.

Podjęto próbę uchwycenia kierunków i trendów badań w zakresie architektury informacji. Przedstawiona analiza nie jest kompletna, bo uwzględnia tylko piśmiennictwo zarejestrowane w wykorzystanych bazach bibliograficznych i bazach cytowań oraz serwisach internetowych udostępniających informacje o publikacjach monograficznych. Wykorzystane źródła można jednak uznać za najbardziej kompletne rejestry piśmiennictwa badanej dziedziny, jakkolwiek nie uwzględniają one wszystkich publikacji ukazujących się na świecie. Dalsze poszukiwania literatury, która nie została zarejestrowana w tych źródłach wymagałoby dużego nakładu czasu, a jego rezultaty z dużym prawdopodobieństwem nie wpłynęłyby znacząco na końcowe wnioski przedstawionego badania. Ponadto warto byłoby przeprowadzić bardziej pogłębioną analizę tematyczną zgromadzonej literatury, na co jednak zabrakło miejsca w tym artykule.

\section{Załącznik 1. Wykaz książek zgromadzonych do analizy}

Arango, J. (2018). Living in Information: Responsible Design for Digital Places. Brooklyn, NY: Two Waves Books.

Bakalov, F. (2010). Designing Information Architecture of Websites. Lambert Academic Publishing.

Baofu, P. (2008). The future of information architecture: conceiving a better way to understand taxonomy, network, and intelligence. Oxford, UK: Chandos Publishing.

Batley, S. (2007). Information Architecture for Information Professionals. Oxford: Chandos Publishing.

Blokdyk, G. (2015). Information architecture - simple steps to win, insights and opportunities for maxing out success. COMPLETE Publishing.

Blokdyk, G. (2017a). Enterprise Information Architecture EIA: End-To-End Data Analysis. CreateSpace Independent Publishing Platform. 
Blokdyk, G. (2017b). Information Architecture Complete Self-Assessment Guide. CreateSpace Independent Publishing Platform.

Blokdyk, G. (2018). Enterprise Information Architecture: Third Edition. CreateSpace Independent Publishing Platform.

Boiko, B. (2017). Information Architecture from the Info Out: Book two in the infoOut series. Independently published.

Boucadair, M., Binet, D. (2013). Solutions for Sustaining Scalability in Internet Growth. IGI Global. https://doi.org/10.4018/978-1-4666-4305-5

Brandon, D. M. (2008). Software engineering for modern web applications: Methodologies and technologies. IGI Global. https://doi.org/10.4018/978-1-59904-492-7

Brown, D. M. (2006). Communicating Design: Developing Web Site Documentation for Design and Planning. Berkeley, CA: New Riders.

Brown, D. M. (2010). Communicating Design: Developing Web Site Documentation for Design and Planning. Berkeley, CA: New Riders.

Brown, P. (2003). Information Architecture with XML: A Management Strategy. Chichester, West Sussex, England ; Hoboken, NJ, USA: Wiley.

Caprio, L., Ghiglione, B. (2003). Information architecture. Milano: Tecniche nuove.

Cook, M., Books, H.-P. P. (1996). Building Enterprise Information Architectures: Reengineering Information Systems. Upper Saddle River, NJ: Prentice Hall.

Courage, C., Baxter, K. (2005). Understanding Your Users. Elsevier Inc. https://doi.org/10.1016/ B978-1-55860-935-8.X5029-5

Covert, A. (2014). How to Make Sense of Any Mess: Information Architecture for Everybody. CreateSpace Independent Publishing Platform.

Dade-Robertson, M. (2011). The Architecture of Information: Architecture, Interaction Design and the Patterning of Digital Information. Abingdon, Oxon; New York: Routledge.

Davis, N. (2015). Information Architecture: Theory, Science and Practice. Elsevier Science \& Technology.

Dijck, P. V. (2003). Information Architecture for Designers: Structuring Websites for Business Success. Mies, Switzerland Hove: Rotovision.

Ding, W., Lin, X. (2010). Information Architecture: The Design and Integration of Information Spaces. Morgan \& Claypool Publishers.

Ding, W., Lin, X., Zarro, M. (2017). Information Architecture: The Design and Integration of Information Spaces. San Rafael: Morgan \& Claypool Publishers.

Evernden, R., Evernden, E. (2003). Information First: Integrating Knowledge and Information Architecture for Business Advantage. London; New York: Butterworth-Heinemann.

Gilchrist, A., Mahon, B., eds. (2003). Information Architecture: Designing Information Environments for Purpose. New York: Facet Pub.

Glushko, R. J., ed. (2013). The Discipline of Organizing. Cambridge, MA: The MIT Press.

Godinez, M., Hechler, E., Koenig, K., Lockwood, S., Oberhofer, M., Schroeck, M. (2010). The Art of Enterprise Information Architecture: A Systems-Based Approach for Unlocking Business Insight. Upper Saddle River, NJ: IBM Press.

Goldschmidt, H. M. J., Cox, M. J. T., Grouls, R. J. E., Van De Laar, W. A. J. H., Van Merode, F. G. G. (1998). Reference information model for clinical laboratories: RILA as laboratory management toolbox (T. 55). IOS Press. https://doi.org/10.3233/978-1-60750-899-1-i

Gotz, R. (2012). Practical SharePoint 2010 Information Architecture. New York, NY: Apress.

Governor, J., Hinchcliffe, D., Nickull, D. (2009). Web 2.0 Architectures: What entrepreneurs and information architects need to know. Sebastopol, CA: O’Reilly.

Greenberg, J., Méndez, E. (2013). Knitting the Semantic Web. Taylor and Francis. https://doi. org/10.4324/9780203052051 
Hausman, K. K., Cook, S. L. (2010). IT Architecture For Dummies. Hoboken, NJ: For Dummies.

Hedden, H. (2016). The Accidental Taxonomist.

Hinton, A. (2014). Understanding Context: Environment, Language, and Information Architecture. Sebastopol, CA: O’Reilly Media.

Information Resources Management Association. (2015). Web design and development: Concepts, methodologies, tools, and applications. IGI Global. https://doi.org/10.4018/978-1-4666-8619-9

Jamil, George Leal. (2015). Handbook of Research on Information Architecture and Management in Modern Organizations. (J. Poças-Rascão, F. Ribeiro, A. M. da Silva, eds.). Hershey, PA: IGI Global.

Jamil, G.L., Poças-Rascão, J., Ribeiro, F., \& da Silva, A. M. (2015). Handbook of research on information architecture and management in modern organizations. IGI Global. https://doi.org/10.4018/978$1-4666-8637-3$

Kalbach, J. (2007). Designing Web navigation. Beijing; Sebastopol: O’Reilly.

Kauhanen-Simanainen, A. (2007). Corporate Literacy: Discovering the Senses of the Organisation. Elsevier Ltd. https://doi.org/10.1016/C2013-0-16637-8

Mahon, B., Hourican, R., \& Gilchrist, A. (2002). Research into information architecture: the roles of software, taxonomies and people: a report. London: Tfpl Ltd.

McKee, J. (2012). Applying principles from IT architecture to strategic business planning. IGI Global. https://doi.org/10.4018/978-1-4666-2527-3

Minoli, D. (2008). Enterprise architecture A to Z: Frameworks, business process modeling, SOA, and infrastructure technology. CRC Press. https://doi.org/10.1201/9781420013702

Morrogh, E. (2002). Information Architecture: An Emerging 21st Century Profession. Upper Saddle River, NJ: Pearson.

Morville, P. (2005). Ambient Findability: What We Find Changes Who We Become. Beijing; Sebastopol, CA: O’Reilly Media.

Morville, P., Callender, J. (2010). Search Patterns: Design for Discovery. Sebastopol, CA: O’Reilly Media

Morville, P., Rosenfeld, L. (1998). Information Architecture for the World Wide Web: Designing Large-scale Web Sites (1 edition). Cambridge; Sebastopol, CA: O'Reilly Media.

Morville, P., Rosenfeld, L. (2006). Information Architecture for the World Wide Web: Designing Large-Scale Web Sites, 3rd Edition (3rd edition). Sebastopol, CA: O’Reilly Media.

O'Brien, H., \& Cairns, P. (2016). Why engagement matters: Cross-disciplinary perspectives of user engagement in digital media. Springer International Publishing. https://doi.org/10.1007/978-3-319-27446-1

Österberg, M. (2016). Web Strategy for Everyone. Intranätverk. Pobrano z http://webstrategyforeveryone.com/

Powell, M. (2003). Information Management for Development Organisations. Oxfam.

Redish, J. G. (2007). Letting Go of the Words. Elsevier Inc. https://doi.org/10.1016/B978-0-12-3694867.X5000-9

Reiss, E. L. (2000). Practical Information Architecture: A Hands-On Approach to Structuring Successful Websites. Harlow: Addison-Wesley Professional.

Resmini, A., ed. (2014). Reframing Information Architecture. Springer International Publishing

Resmini, A., Rosati, L. (2011). Pervasive Information Architecture: Designing Cross-Channel User Experiences. Burlington, MA: Morgan Kaufmann.

Rosenfeld, L. (2011). Search Analytics for Your Site: Conversations with Your Customers. Brooklyn, N.Y: Rosenfeld Media, LLC.

Rosenfeld, L., Morville, P. (2002). Information Architecture for the World Wide Web: Designing Large-Scale Web Sites, 2nd Edition. Cambridge, Mass: O’Reilly Media.

Rosenfeld, L., Morville, P., Arango, J. (2015). Information Architecture: For the Web and Beyond (4 edition). Sebastopol, CA: O’Reilly Media.

Russell-Rose, T., Tate, T., eds. (2013). Designing the search experience: the information architecture of discovery. Amsterdam: Elsevier, Morgan Kaufmann. 
Sabharwal, A. (2015). Digital Curation in the Digital Humanities: Preserving and Promoting Archival and Special Collections. Elsevier Ltd. https://doi.org/10.1016/C2014-0-02808-0

Saravanan, T. (2012). Information Architecture: A Multidisciplinary Text Book. Ess Ess Publications.

Schmitt, G. (1999). Information Architecture: Basics and Future of Caad. Springer Science \& Business Media.

Shanley, C. (2016). Cracking Information Architecture: The definitive field guide for designers, business managers and project teams. eBook: Colin Shanley: Books.

Shepard, D. (2016). The Information Architecture Handbook - Everything You Need to Know about Information Architecture. Emereo Pty Limited.

Shivakumar, S. K. (2016). Enterprise Content and Search Management for Building Digital Platforms. Wiley-IEEE Press. https://doi.org/10.1002/9781119206842

Spencer, D. (2009). Card Sorting: Designing Usable Categories. Rosenfeld Media.

Spencer, D. (2010). A Practical Guide to Information Architecture. Victoria, Australia: UX Mastery.

Stackowiak, R., Licht, A., Mantha, V., Nagode, L. (2015). Big Data and The Internet of Things: Enterprise Information Architecture for A New Age. New York: Apress.

Steenson, M. W. (2017). Architectural Intelligence: How Designers and Architects Created the Digital Landscape. Cambridge, MA: The MIT Press.

Tupper, C. (2011). Data Architecture: From Zen to Reality. Burlington, MA: Morgan Kaufmann.

Valverde, R., \& Talla, M. R. (2012). Information systems reengineering for modern business systems: ERP, supply chain and e-commerce management solutions. IGI Global. https://doi.org/10.4018/9781-4666-0155-0

Wachter-Boettcher, S. (2012). Content Everywhere: Strategy and Structure for Future-Ready Content. Brooklyn, N.Y: Rosenfeld Media.

Weber, R. H., Weber, R. (2010). Internet of things: Legal perspectives. Springer Berlin Heidelberg. https://doi.org/10.1007/978-3-642-11710-7

Wodtke, C. (2002). Information Architecture: Blueprints for the Web. Boston: New Riders.

Wodtke, C., Govella, A. (2009). Information Architecture: Blueprints for the Web (2 edition). Berkeley, CA: New Riders.

Wurman, R. S. (1997). Information Architects. Zürich: Graphis Inc.

$\mathrm{Xu}, \mathrm{L} . \mathrm{D} .(2014)$. Enterprise Integration and Information Architecture: A Systems Perspective on Industrial Information Integration. Boca Raton: Auerbach Publications.

\section{Bibliografia}

Chadegani, A. A., Salehi, H., Yunus, M. M., Farhadi, H., Fooladi, M., Farhadi, M., Ebrahim, N. A. (2013). A comparison between two main academic literature collections: Web of science and scopus databases. Asian Social Science, 9(5), 18-26, [9.03.2019], https://doi.org/10.5539/ass.v9n5p18

Falagas, M. E., Pitsouni, E. I., Malietzis, G. A., \& Pappas, G. (2008). Comparison of PubMed, Scopus, Web of Science, and Google Scholar: strengths and weaknesses. The FASEB Journal, 22(2), 338-342, [9.03.2019], https://doi.org/10.1096/ff.07-9492LSF

Garshol, L. M. (2004). Metadata? Thesauri? Taxonomies? Topic maps! Making sense of it all. Journal of Information Science, 30(4), 378-391.

Kalbach, J. (2012). Projektowanie nawigacji strony WWW: Optymalizacja funkcjonalności witryny. Gliwice: Helion.

León, R. R. (2014). Information Architecture: historical-conceptual analysis. Rodrigo Ronda León. UX, Graphic \& Web Designer [9.03.2019], http://www.rodrigorondaleon.com/documents/Information_architecture_historical-conceptual_analysis.pdf

Morville, P., Callender, J. (2011). Wzorce wyszukiwania: projektowanie nowoczesnych wyszukiwarek. Gliwice: Helion. 
Morville, P., Rosenfeld, L. (1998). Information Architecture for the World Wide Web: Designing Large-scale Web Sites. Sebastopol, CA: O'Reilly.

Resmini, A., Rosati, L. (2011). Pervasive Information Architecture: Designing Cross-Channel User Experiences. Burlington, MA: Morgan Kaufmann.

Resmini, A., Rosati, L. (2012). A Brief History of Information Architecture. Journal of Information Architecture, 3(2) Information Architecture for the World Wide Web: Designing Large-scale Web Sites [9.03.2019], http://journalofia.org/volume3/issue2/03-resmini/

Rosenfeld, L., Morville, P., Arango, J. (2017). Architektura informacji w serwisach internetowych i nie tylko (4. wyd.). Gliwice: Helion.

Rosenfeld, L., Morville, P. (2003). Architektura informacji w serwisach internetowych. Gliwice: Helion.

Skórka, S. (2002). Architektura informacji Nowy kierunek rozwoju informacji naukowej. EBIB Elektroniczny Biuletyn Informacyjny Bibliotekarzy, 40(11), [9.03.2019], http://www.ebib.pl/2002/40/ skorka.php

Skórka, S. (2016). Architektura informacji. W: W. Babik (red.), Nauka o informacji (s. 555-575). Warszawa: Wydaw. SBP.

Sosińska-Kalata, B. (2007). Współczesne oblicze nauki o informacji w Polsce i za granicą. W: E. Gondek, D. Pietruch-Reizes (red.), Studia z informacji naukowej i dyscyplin pokrewnych. Prace dedykowane Profesor Barbarze Stefaniak (93-119). Katowice: Wydaw. Uniwersytetu Śląskiego.

Tafiłowski, P. (2016). Architektura informacji jako problem badawczy informatologii. Zagadnienia Informacji Naukowej, 54(2), 37-47.

\title{
Information Architecture in Foreign Literature 1982-2018. Quantitative Analysis
}

\begin{abstract}
Purpose/Thesis: The aim of the article is to present the process of shaping interest in information architecture in world literature.

Approach/Methods: A bibliographic analysis of subject literature published until the end of 2018 was carried out to examine the development of information architecture literature. The literature was identified in Scopus, Web of Science and Library and Information Science Abstract, and the Google Scholar, Google Books services and Amazon Bookstore. The quantitative analysis of the chronological and thematic distribution of literature is complemented by the identification of the most important authors, books and journals, as well as the most frequently cited publications.

Results and conclusions: 2269 publications on information architecture were identified. They varied in topics, covering mainly information systems and information science issues. The results of the analysis indicate that interest in various aspects of information architecture has been steadily increasing since 2000, as confirmed by the growing number of publications and their citations.

As a result of the conducted query, a collection of 2269 publications on a wide range of topics, mainly in the field of information systems and information science, was created. The results of the analysis indicate that interest in various aspects of information architecture has been continuously increasing since 2000, which was confirmed by the growing number of publications and their citations.

Originality/Value: No attempts in Polish publications have been made to analyze literature in the field of information architecture. The article can be a starting point for in-depth thematic analysis and can serve as a comparative material for similar studies.
\end{abstract}




\section{Keywords}

Bibliometric analysis. Information architecture. Information science. Information systems architecture. Quantitative analysis of literature.

Dr ANNA MATYSEK jest adiunktem w zakładzie Zarzadzania Informacja w Instytucie Bibliotekoznawstwa i Informacji Naukowej Uniwersytetu Ślaskiego w Katowicach. Jej zainteresowania badawcze skupiaja sie wokót problematyki normalizacji w dziatalności informacyjnej, ilościowych badań informacji, architektury informacji i wyszukiwania informacji. Ważniejsze publikacje: Normalizacja europejska w zakresie informatologii, Katowice 2014. Cytowania dokumentów elektronicznych w wydawnictwach naukowych. Nowa Biblioteka 2017, nr 4(27) s. 53-68. Otwarte czasopisma w naukach humanistycznych. Analiza ilościowa na przyktadzie bibliologii i informatologii. Nowa Biblioteka 2018, nr 2 (29) s. 65-81.

Kontakt $z$ autorka:

anna.matysek@us.edu.pl

Adres do korespondencji:

Instytut Bibliotekoznawstwa i Informacji Naukowej

Uniwersytet Ślaski w Katowicach

pl. Sejmu Śląkiego 1

40-032 Katowice 